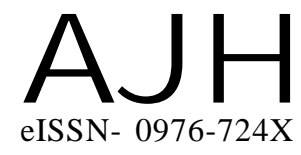

Received : 08.02.2017

Revised : 18.04 .2017

Accepted : 03.05.2017
Members of the Research Forum

Associated Authors:

${ }^{1}$ College of Horticulture,

BAGALKOT (KARNATAKA) INDIA
Author for correspondence :

V.P. SINGH

College of Horticulture, BAGALKOT (KARNATAKA) INDIA

Email : vpsingh.neev@gmail.com
THEASIAN JOURNALOF HORTICULTURE Volume 12 | Issue 1 | June, 2017 | 28-34

Visit us -www.researchjournal.co.in

\section{Effect of growth regulation through spacing and pruning on yield and quality of tomato hybrids (Lychopersicon esculentum Mill.) grown under control conditions}

\section{SHARNABASAVA ${ }^{1}$, Y.C.VISHWANATH ${ }^{1}$, I.N. NAGARAL ${ }^{1}$, V.P. SINGH, AND B.S. HARISH ${ }^{1}$}

ABSTRACT : An experiment was conducted at Indian Institute of Horticultural Sciences, Bangalore to study the effect of growth regulation through spacing and pruning on yield and quality of tomato hybrids (Lychopersicon esculentum Mill.) grown under control conditions. The results of present investigation revealed that tomato variety Sun $7611\left(\mathrm{~V}_{2}\right)$ recorded the higher $(7.42,7.90,4.63$ and 1.85) number of flowers per cluster at all the stages of crop growth and differed significantly from Arka Abhijith $\left(\mathrm{V}_{1}\right)$. Where in pruning methods single stem $\left(\mathrm{P}_{1}\right)$ gave higher (6.74 and 7.09) number of flowers per cluster at 30 and 60 days after transplanting, which were significantly different from $\mathrm{P}_{2}$ (double stem). Tomato grown on single-stem resulted in higher individual fruit weight $(77.04 \mathrm{~g})$ than double stemmed plants. Maximum yield of 2.23 $\mathrm{kg} / \mathrm{plant}$ and 129.4 tonnes per hectare was recorded in plants having two stemmed plant, and the yield of $1.96 \mathrm{~kg}$ per plant and 114.38 tons per hectare was obtained from single - stemmed plants. Plants wider spacing gave the highest fruit weight $(79.15 \mathrm{~g})$ followed by medium spacing plants $(73.92 \mathrm{~g})$ and the least was recorded in closely spacing plants $(69.07 \mathrm{~g})$. Fruit yield per plant was significantly reduced under closer plant spacing $(1.8 \mathrm{~kg})$ and increased as spacing were increased.

KEY WORDS : Growth regulation, Spacing, Pruning, Quality, Tomato hybrids

HOW TO CITE THIS ARTICLE : Sharnabasava, Vishwanath, Y. C., Nagaral, I. N., Singh, V. P. and Harish, B.S. (2017). Effect of growth regulation through spacing and pruning on yield and quality of tomato hybrids (Lychopersicon esculentum Mill.) grown under control conditions. Asian J. Hort., 12(1) : 28-34, DOI : 10.15740/HAS/TAJH/12.1/28-34. 